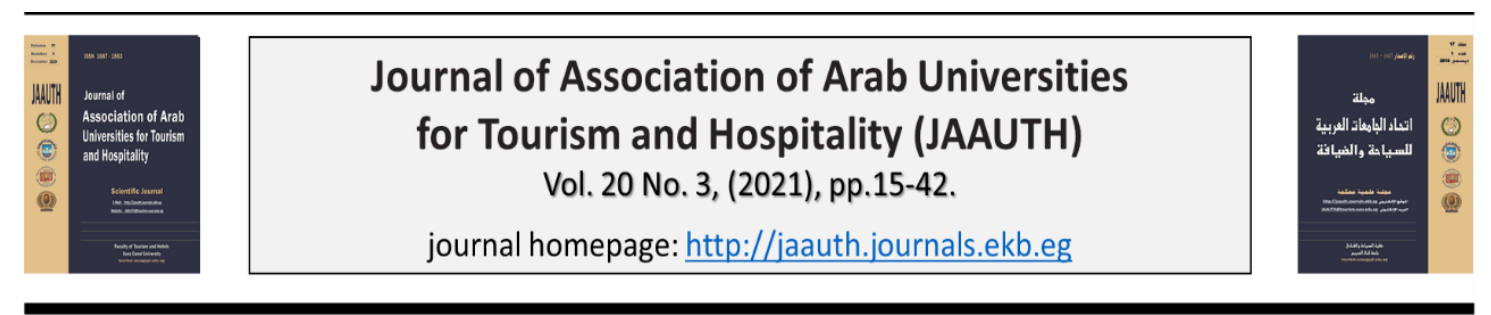

\title{
Goddess Sopdet in Ancient Egyptian Religion
}

\author{
Mona Ezz Ali \\ Associate Professor, Faculty of Tourism and Hotels , Mansoura University
}

\section{ARTICLE INFO ABSTRACT}

Keywords:

Sopdet; Sothis; Isis; Sirius; Saft el Hinna.
This paper deals with one of the astral goddesses in Ancient Egyptian religion, Sopdet; she was goddess of the brightest star in the southern sky. She personified the Dog Star, Sirius, she was known as Sothis to the Greeks $\mathbf{\Sigma} \hat{\omega} \theta \boldsymbol{\iota s}$, she was worshipped at Saft el-Hinna. Sopdet was known as the wife of god sah (Orion) $)^{1}$ and mother of god Sopdu ${ }^{2}$, she was associated to many deities like Isis in the form of Isis Sothis, she was known since the first Dynasty as the goddess who brings the new year and the innundation, as each year the coming of the flood coincided with the moment of its brightness on the horizon at dawn after its absence for about 70 days (This phenomenon is called a heliacal rising of Sothis. $)^{3}$, so she was considered as a fertility goddess because of the soil braught by the flood her appearance also corresponded with the beginning of the ancient Egyptian year ${ }^{4}$, and she was considered as the queen of all decans, as she preceded all the stars .5 She appeared in different forms, as she appeared in a human form, a cow, a lioness headed serpent, and a dog headed serpent.she is characterized by many qualities and titles. The research studies the archaeological and textual evidences of goddess Sopdet referring to her titles, qualities, forms, roles and her relations to other deitie.

\section{Introduction}

\section{The astral deities:}

The ancient Egyptians interested in the stars, as they helped them for determining the times and seasons. They represented the astral deities in their coffins, temples, and tombs from the Middle Kingdom until the Greco roman periods. They depicted the stars which represented the river of the Milky Way and they assumed that it is the residence of the heavenly river, in which the gods sailing with their barks. The most famous stars which the ancient Egyptian texts referred to were two groups of stars in the southern sky and the stars in the northern sky which are visible every night. $^{6}$ 


\section{Saft el-Hinna}

Goddess Sopdet was worshipped at Saft el-Hinna . It is located in the eastern Delta, About $11 \mathrm{~km}$ south east of Zagazig. Its ancient name was ${ }^{\circ} \Delta$ 皮 $\operatorname{Pr~spdw,~"The~}$ place of Soped", It is the cult centre of god sopdu, god of the eastern borders of egypt. The site was excavated by E. Naville in 1885 that discovered few monuments there like granite clossal statue for Ramses II, a naos of Nectanebo I, dedicated to god Sopdu, and a black granite stele of Ptolemy ii, while its cemetery was excavated by Fli. Petrie in 1967.

\section{The name}

$\Lambda \star$

a spd.t is the goddess who personified the dog star. ${ }^{8}$ And the masculine of this

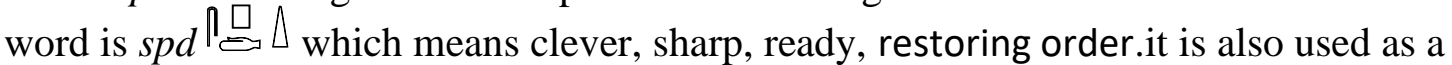
determinative for geometric figure (triangle) and loaf, ${ }^{9}$ while The Greek name, 'sirius, $\mathbf{\Sigma} \hat{\omega} \theta \mathbf{\iota s}$ means ', 'shining', sparking' 'fiery' or 'burning'the masculine for spd.t is spd. ${ }^{10}$

Sopdet was written with different ideograms, as her name appeared in many forms through the different periods ${ }^{11}$

During Old Kingdom her name was engraved in the following forms

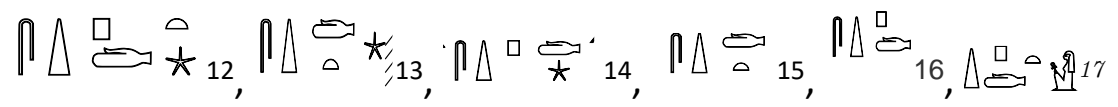

During Middle Kingdom her name was engraved in the following forms

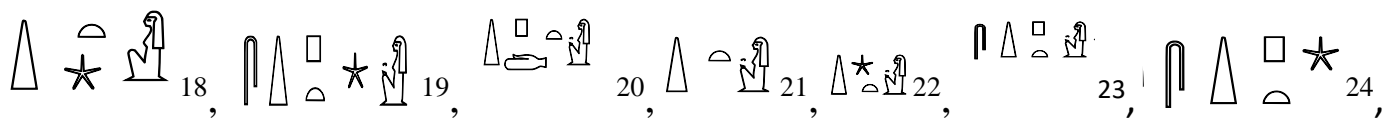

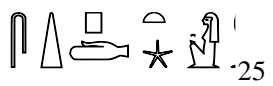

During New Kingdom her name was engraved in the following forms

$$
ף \Delta_{\star 26}^{\circ}, \Delta_{0}^{\star}{ }_{27}^{\star}, \square \Delta_{0}^{\star} ._{28}
$$

During Late Period her name was engraved in the following forms

$$
\Delta \text { 太近 } 29, \Delta \text { 鸟。 }
$$

During Greco - Roman periods her name was engraved in the following forms

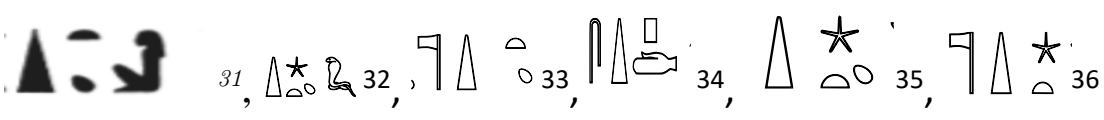

It is noticed from the previous forms in which the name of Sopdet were written that they ended with one of the following determinatives

$\star$, ก 


\section{- Sopdet at the sacred texts}

- Sopdet in Pyramid texts

Pyr. 151b

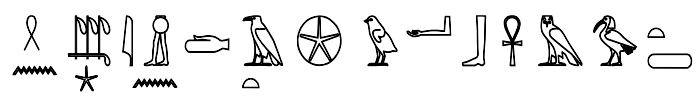

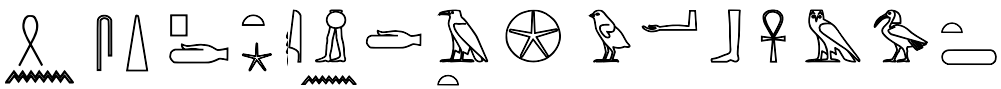

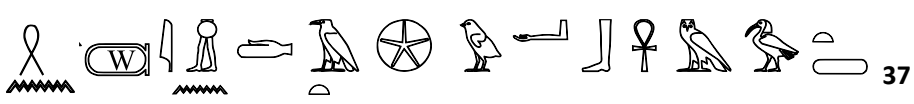

, šn s3h in d3t web enh $m$ 3ht, šn spd.t in d3t web enh $m$ 3ht, šn wnis pn in d3t web enh $m$ 3ht

Sah is swallowed by the duat, pure and living in the horizon, Sothis is swallowedby the duat, pure and living in the horizon, the deceased king is swallowed by the duat, pure and living in the horizon.

This spell implies that the king is a star which disappears into the netherworld at dawn on the eastern Akhet in parallel with sah and Sopdet. The expression of being encircled by the Duat, is used to refer to the heliacal setting of stars.

Pyr. 341c; Pyr.1707a.

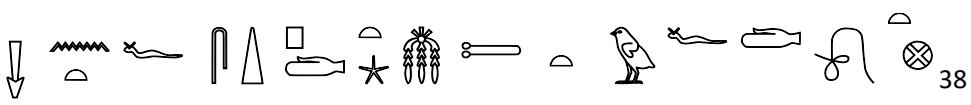

snt.f spdt mstwt.f dw3t

"His sister is Sothis, his offspring is the Morning Star (the dawn)"

Pyr. 357a.

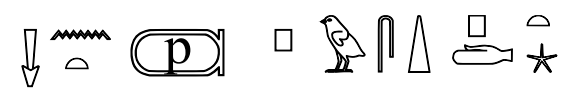

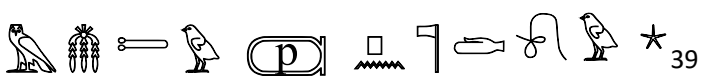

snt ppi pw spdt mstwt ppi pn ntr d3t

The sister of Pepi is Sothis; the offspring of Pepi is this morning star.

Pyr.363a.

防要

snt ppi pw spdt

The sister of pepi is Sothis; [the offspring of N. is the morning star]

Pyr. 458a; 1482a

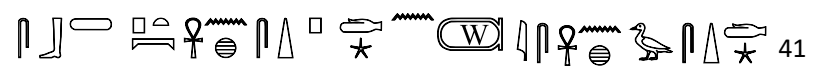


sb̌̌ pt enh spd $n$ wnis is enh s3 spdt

The sky is clear and Sothis lives, for Unis is the living one, the son of Sothis.

Pyr. 459b

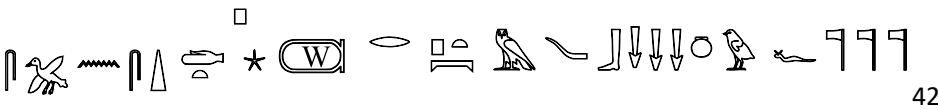

" sp3 $n$ spdt $\mathrm{N}$ r pt m- cb snw.f ntrw"

Sopdet caused the deceased king $\mathrm{N}$ to fly to the sky among his brothers the gods

Pyr.632c

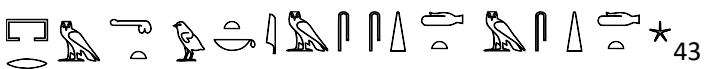

pr mtwt.k im.s spdt m spdt

that your seed may go into her, (while) it is sharp like Sothis.

Pyr.689 b-e

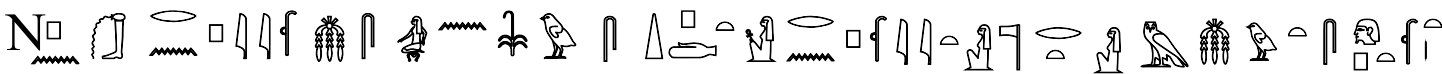

" $\mathrm{N}$ pn web rnpy ms.n sw spdt rnpyt rnpt ntrt $m$ mswt.s tpy rnpt "\$44

$\mathrm{N}$ is pure and young and Sopdet born him, she is the young, she is of the year, a goddess from her birth is the start of the year

In this spell Sopdet acted as the mother of the deceased in her role as bringing the new year, referring to her heliacal rising.

Pyr.723a. ${ }^{45}$

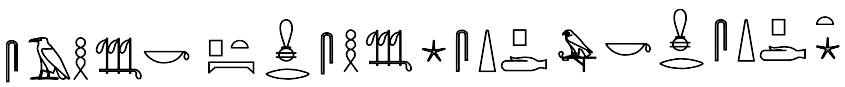

s3h.k pt mi - iry s3h spd b3.k mi - iry spdt

(when) You tiptoe or reach the sky like Orion, your soul shall be sharp like Sothis

Faulkner noted that $s p d t$ also means 'restoring order. besides, goddess Sopdet was known 'being effective' and 'restoring order', because she was known as heralding the inundation of the Nile, so comparing the soul of the king with Sothis implies that the king's bA will be effective in restoring order like Sothis. ${ }^{46}$

Pyr. 822a.

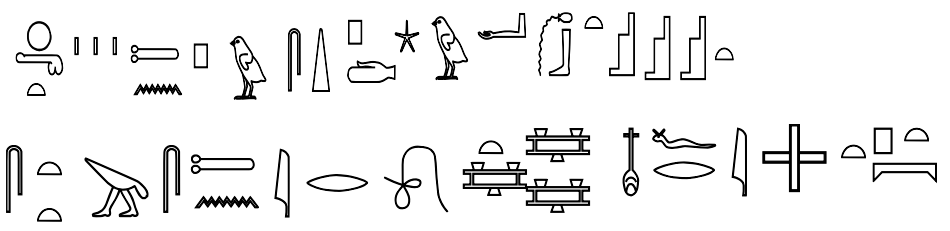

$\underline{h} m t$. $\underline{\text { tn }}$ pw spdt webt swt š̌m.s tn ir w3wt nfr im(y)t pt 
Sothis it is your third ${ }^{47}$ of the pure places, she leads you on the beautiful ways in the sky.

Pyr. 929b; ${ }^{48} 935 c^{49}$

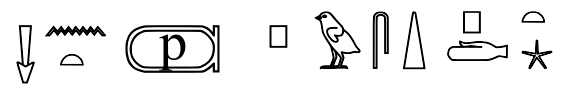

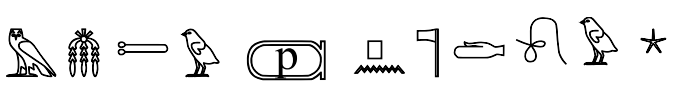

snt ppi pw spdt mstwt ppi pn ntr dw3t

the sister of $\mathrm{N}$. is Sothis; the offspring of $\mathrm{N}$. is the morning star.

Pyr. 965a-b

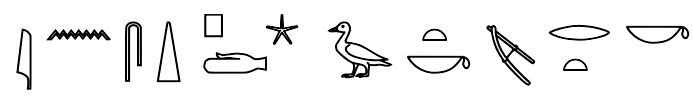

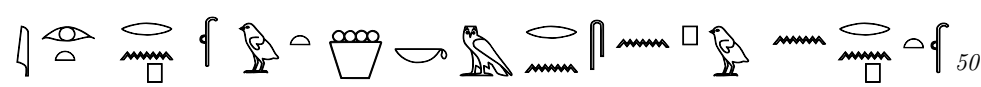

(N) in spd.t s3t.k mrt.k irt rnpwt.k $m$ rn.s $n$ pw n(i) rnp.t“

It is Sothis, your daughter, who loves you, who makes your fresh yearly sustenance, in this her name of year."

Pyr. $1082 d^{51} ; 1152 b^{52}$

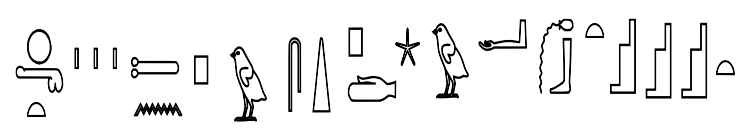

$\underline{h} m t-n w \cdot \underline{t} n$ pw spdt webt iswt

Your third is Sothis of the pure places.

Pyr. 1123b.

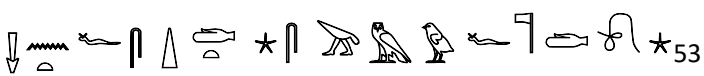

snt.f spdt sšm.f ntr $d w 3 t$

his sister is Sothis; his guide is the morning star

Pyr. 1437a.

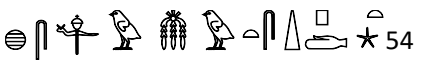

hsfwt mswt spdt

The birth of Sothis shall be opposed.

Pyr. 1561 b

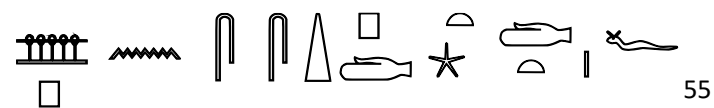

" šsp spdt drt.f", 
Sopdet shall take his hand

- Coffin texts

CT I17d, spell 6

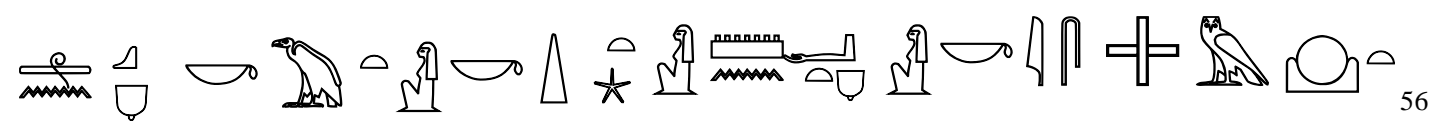

snk. $k$ mwt.k spdt mnet. $k$ is imyt $3 h t$

You suckle from your mother Sothis, she is as your nurse who is in the horizon

Ct I 143a; 146c spell 36; 37

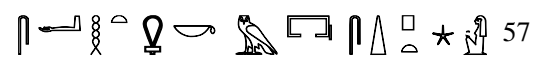

s3h.k $m$ pr spdt

He has been magnified in the house of Sothis

Ct I 188b spell 44

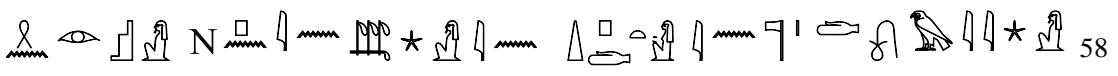

šn wsir $\mathrm{N}$ pn in s3h in spd in nț $d 3 t$

may $\mathrm{N}$ be encircled by Orion, by Sothis and by the sacred morning star

This spell refers to the sunrise, as the deceased (Osiris) is encircled and placed in the arms of the sky-goddess by Orion, Sothis, and the morning star. ${ }^{59}$

Ct v 371b spell 467, vol. ii

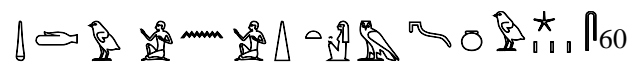

$m d w$ n.i spdt $m$ stpw nw.s

Sothis speaks to me in her good time

Ct v 385b spell 468, vol. ii, p. 99

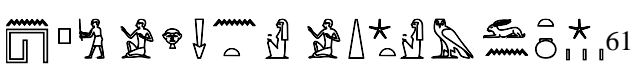

nh3y. i hr snt.i spdt $m$ wnwt

I copulate my sister Sothis in her hours

Ct v 389i spell 469, p. 101

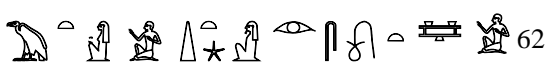

mwt.i spdt iri.s w3t.i sḳr.s rwd $r$

My mother is Sothis, she makes my path

Ct v 399e spell 470

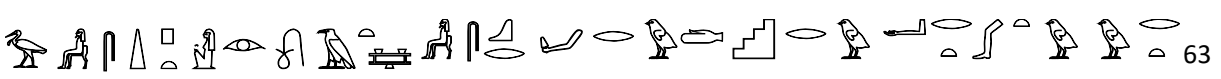


b3 .i spdt ir w3t.i sker rwd $r$ wert tw wrt

My soul is Sothis, she makes my pathway, and carves a stairway to this very great plain

Sothis here acts the same function as the ba of the deceased. ${ }^{64}$

These two spells refer to the role of Sothis in helping the deceased to ascend to the sky, as she builds a stairway for him until he appears on the primeval hill to ascend to the sky. ${ }^{65}$

Ct v 390h spell 469

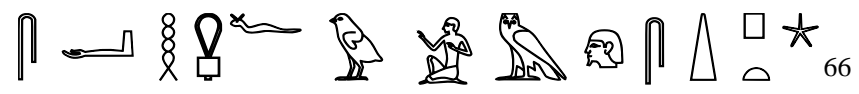

sch.f wi $m$ tp spdt

he venerates me at the head of Sothis

Ct vi 51d spell 482

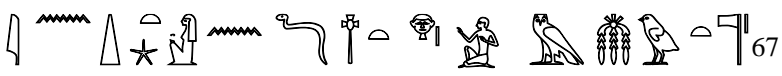

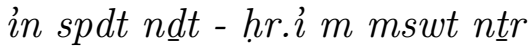

it's Sothis who greats me in the birth of the god

Ct vi $239 m$ spell 623

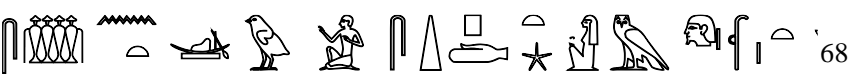

shnt wi spdt $m$ tp rnpt

Sothis will sail me upstream at the first of the year.

Ct vi 319d spell 689

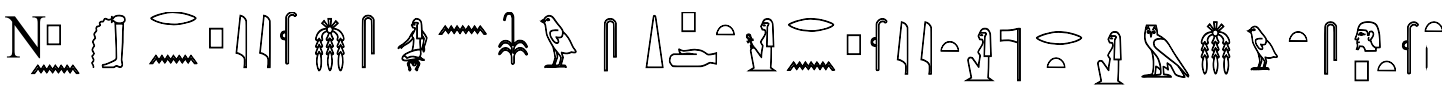

$\mathrm{N}$ pn web rnpy ms.n sw spdt rnpyt ntrt $m$ mswt .s tpy rnpt ${ }^{69}$

$\mathrm{N}$ is pure and young, Sothis has born him, she is the young one, she is of the year, a goddess from her birth is the start of the year

This spell refers to her heliacal rising at the beginning of the year.

- Book of dead

- chapter 110 of book of coming forth by day, Papyrus of Nebseni

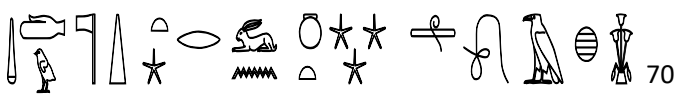

mdw spdt $r$ wnwt.s w3h

Sothis speaks at her hours of the flood 
This spell refers that the heliacal rising of Sothis occurred at the same time when the river Nile rose to its highest point

- Chapter one of book of coming forth by day, Papyrus of Nekhamun, p. 88

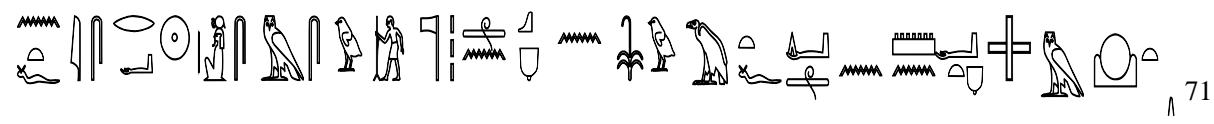

ntf is $\mathrm{Re} s m s w$ ntrw snk $n$ sw mwt.f rdi.s $n$ mnet imy 3 ht

He is god Re, the eldest one of the gods, his mother suckled him, and she gave him a nurse who is in the horizon (Sothis)

In this spell goddess Sopdet wasn't clearly mentioned, but this spell matched with CT I 17d, spell 6 which says

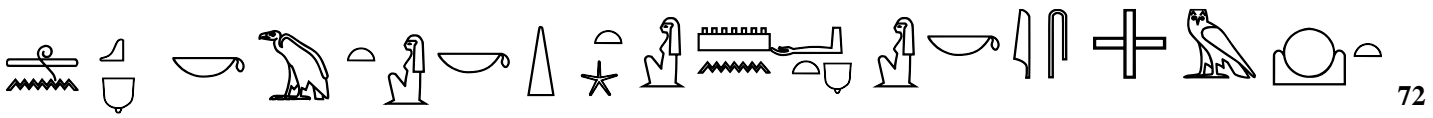

snk. K mwt.k spdt mnet.k is imyt 3ht

You suck at your mother Sothis as your nurse who is in the horizon

These spells refer to the close relation between Re and Sopdet as its heliacal rising refers to its rising just before the sun rise in the horizon, so she nursed and suckled Re at the horizon ${ }^{73}$

\section{Forms of goddess Sopdet}

\section{A- In a human form}

1-as a woman wearing crown with three plumes, surmounted with the sun disc

She appears in a human form in the companion of her consort Orion (osiris) representing the southern sky. They appear while crossing the $\mathrm{sky}^{74}$ in the astronomical scenes decorated temples, tombs, and lids of sarcophagi like the following scenes:

In the astronomical ceiling of Ramesseum, goddess Sopdet appeared inside her celestial boat behind the boat of her consort Orion $(s 3 h)$. She is wearing crown with three plumes, surmounted with the sun disc. She is lifting her right hand and holding the papyrus and $n h$ scepter in the other hand. she is accompanied with text addressing Ramses II saying

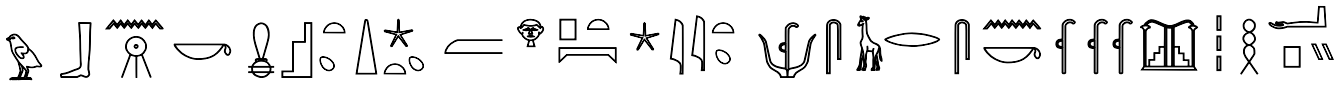
wbn .k mi ist spdt m hrt pt sb3yt wp rnpt sr.s n.k rnpwt hbw hepy "may you shines like Isis Sothis in the starry sky on the day of the beginning of the year, May she foresee for you many festive years and inundations ${ }^{175}$ fig. 1

This text shows the link between the heliacal rising of Sopdet and the inundation. 
The similar scene appeared in tomb of Seti I I fig. 2, tomb of Sennenmut at El Deir El Bahari fig. 3 , tomb of Pedamenope fig. 4 , tomb of Montuemhat fig.5 , and Sarcophagus of Ankhhapy fig.6

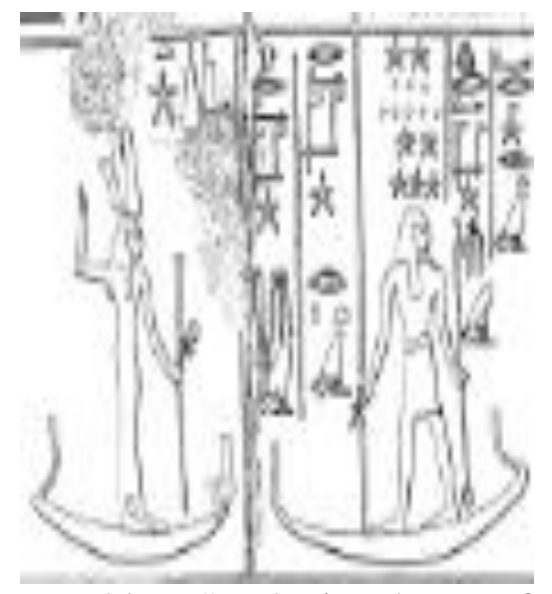

Fig.1. A scene representing goddess Sopdet in a human form inside a celestial boat, $3^{\text {rd }}$ hypostyle hall of Ramesseum temple, $19^{\text {th }}$ dynasty After O.Neugebauer \& R.A.Parker, Egyptian astronomical texts III, london, 1969, pl.5

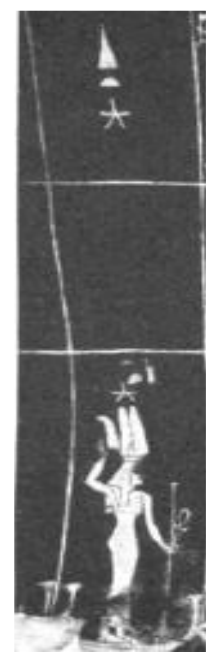

Fig.2. A scene representing goddess Sopdet in a human form inside a celestial boat, Tomb of seti I, $19^{\text {th }}$ dynasty

After S.B. Ludlow, " An Ancient Egyptian Astronomical Ceiling-Decoration", MMAB 18, No. 12, Part 1, Nov., 1923, fig. 6 


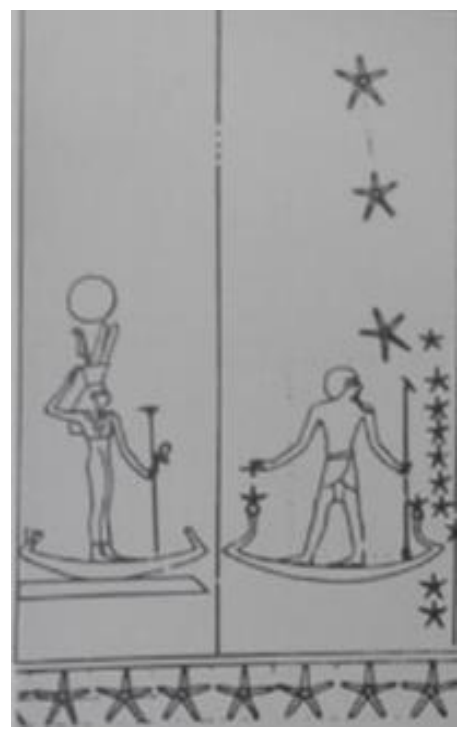

Fig.3. A scene representing goddess Sopdet in a human form inside a celestial boat wearing headdress with three plumes, surmounted with the sun disc, Tomb of senenmut I, $18^{\text {th }}$ dynasty

After M. Shaltout and J.A. Belmonte, the Astronomical Ceiling of Senenmut: A Dream of Mystery and Imagination, Cagliari (2005), fig.1

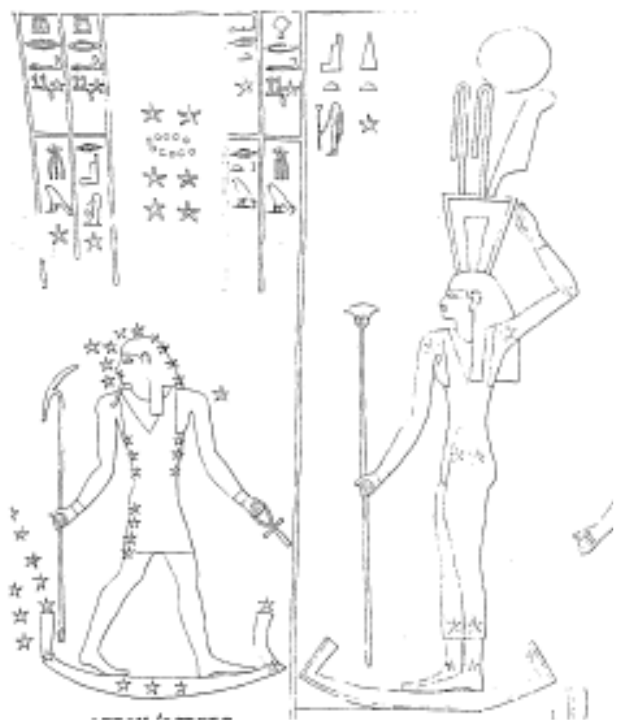

Fig.4. A scene representing goddess Sopdet in a human form inside a celestial boat, tomb of Pedamenope, $26^{\text {th }}$ dynasty After O.Neugebauer \& R.A.Parker, Egyptian astronomical texts,pl. 18 


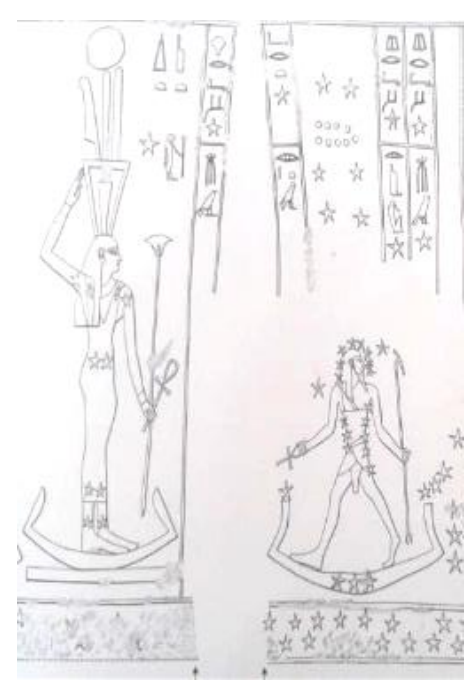

Fig.5. A scene representing goddess Sopdet inside a celestial boat behind Orion, tomb of Montuemhat $26^{\text {th }}$ dynasty

After O.Neugebauer \& R.A.Parker, Egyptian astronomical texts,pl. 20
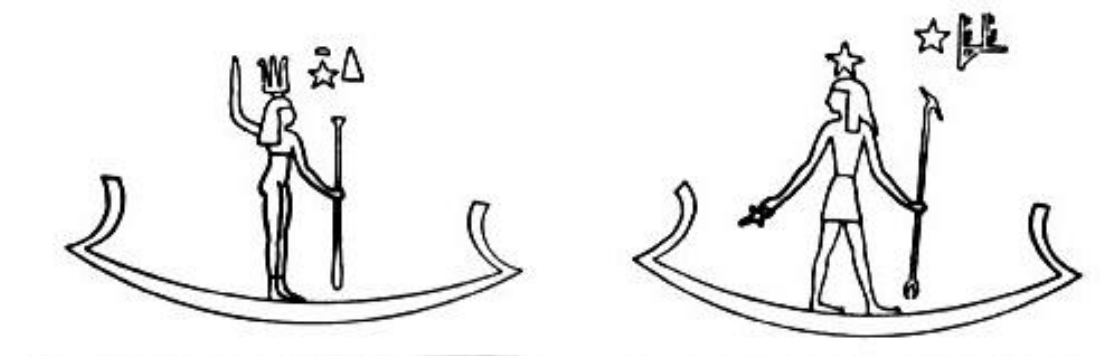

Fig. 6. A scene representing goddess Sopdet wearing headdress with three plumes, crossing the sky inside her celestial boat behind Orion, Sarcophagus of Ankhhapy, 30th dynasty

After O.Neugebauer \& R.A.Parker, Egyptian astronomical texts,fig.13

2-as a woman with the shape of spd $\triangle$ on her head

Sopdet appears in many coffin lids from Assyuit in a human form with the shape of spd $\triangle$ on her head, holding $n h$ in one hand and the w3s in the other hand. She stands beside Orion $(s 3 h)$ representing the southern sky opposite to the northern sky (Nut and mshtyw) , like sarcophagus of hw $n$ skr fig. 7 , Hounnou fig.8, Idy fig.9, It-ib, fig.10, Tefabi fig.11, $\underline{t} 3 w 3 w$ fig.12, Nhti, fig.13 


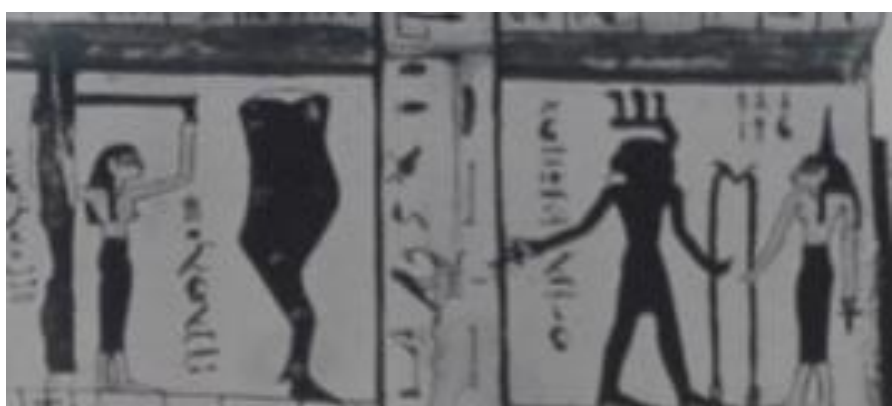

Fig.7. A scene representing goddess Sopdet in a human form with the form of the spd upon her head, the coffin lid of hw $n$ sk

After O.Neugebauer \& R.A.Parker, Egyptian astronomical texts I,1960, pl. 6

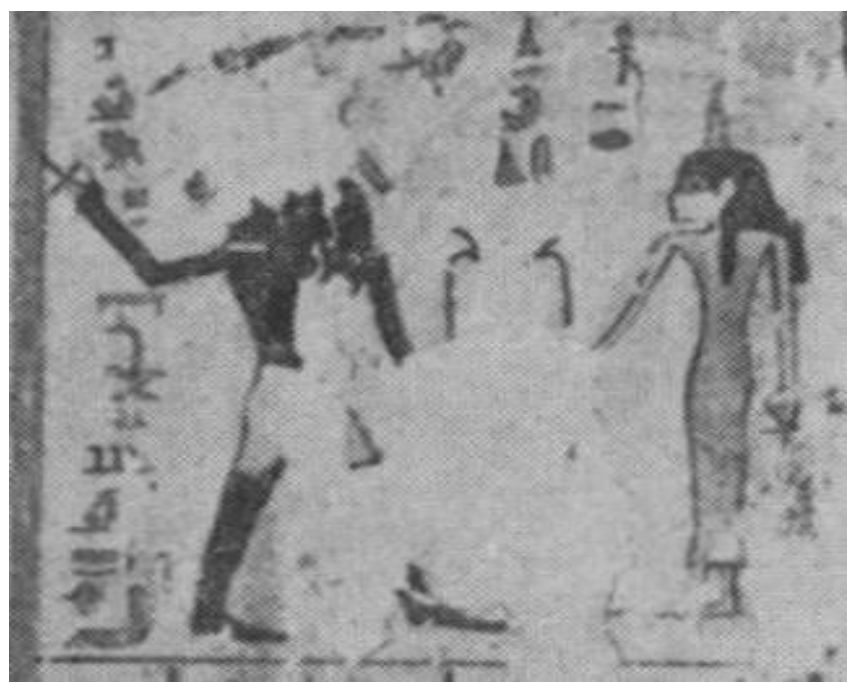

Fig.8. A scene representing goddess Sopdet in a human form with the form of the spd upon her head, the coffin lid of Hounnou

After A. Pogo, " Calendars on Coffin Lids from Asyut (Second Half of the Third Millennium", Isis 17, No. 1 (1932), pl. c

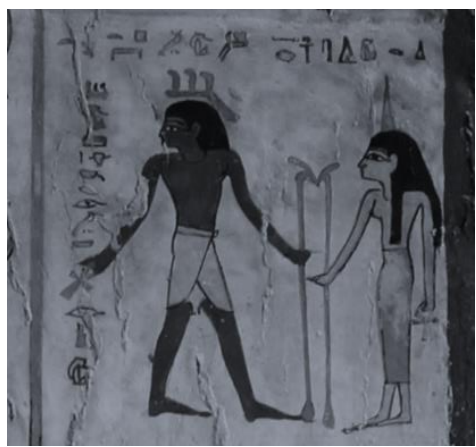

Fig. 9. A scene representing goddess Sopdet in a human form with the form of the spd upon her head, the coffin lid of Idy

After O.Neugebauer \& R.A.Parker, Egyptian astronomical texts I, pl. 8 


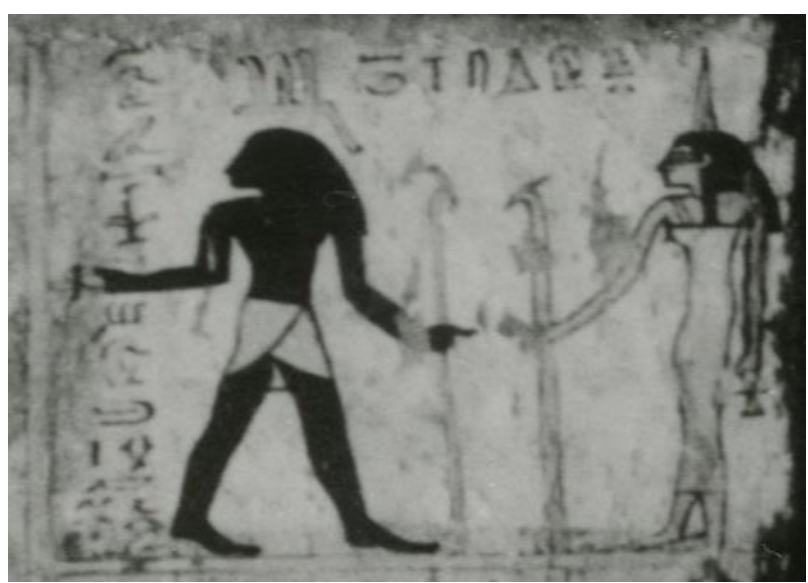

Fig. 10. A scene representing goddess Sopdet in a human form with the form of the spd upon her head, the coffin lid of It-ib After After O.Neugebauer \& R.A.Parker, Egyptian astronomical texts I, pl. 4

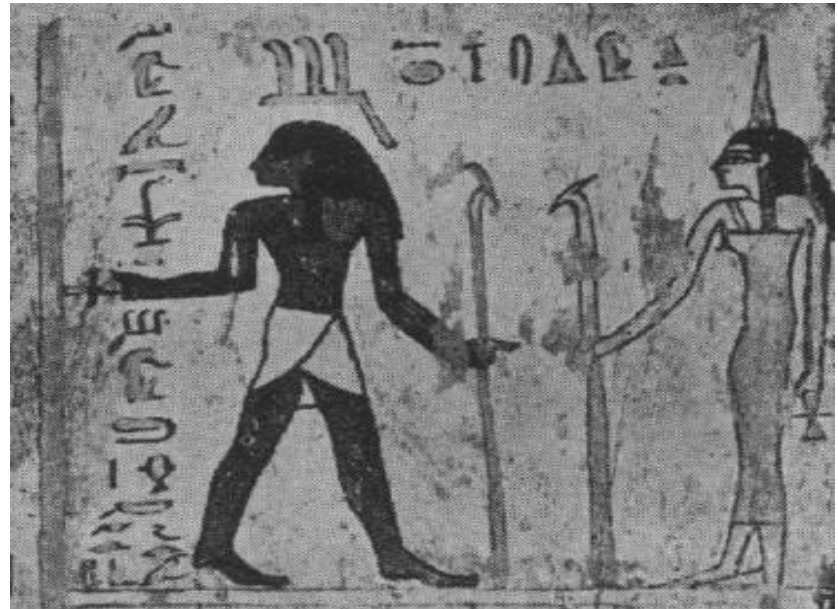

Fig. 11. A scene representing goddess Sopdet in a human form with the form of the spd upon her head, the coffin lid of Tefabi

After A. Pogo, " Calendars on Coffin Lids from Asyut (Second Half of the Third Millennium", Isis 17, No. 1 (1932), pl. E

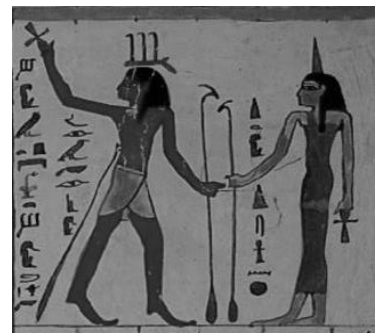

Fig.12. A scene representing goddess Sopdet in a human form with the form of the spd upon her head, the coffin lid of $\underline{t} 3 w 3 w$

After O.Neugebauer \& R.A.Parker, Egyptian astronomical texts I,pl. 19 


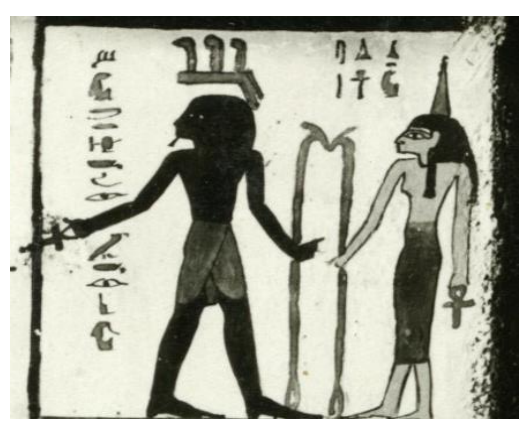

Fig.13. A scene representing goddess Sopdet in a human form with the form of the spd upon her head, the coffin lid of $\mathbf{N} \underline{h} t$

After O.Neugebauer \& R.A.Parker, Egyptian astronomical texts I, pl. 5

3-as a woman with a crown made of many papyrus plants

Goddess Sopdet appeared in a human form wearing a crown made of many papyrus plants, which symbolizes fertility at south wall of room L in temple of Hibis. King Darius presents wine to her (his mother), eye of re " di irp n mwt spdt irt re"

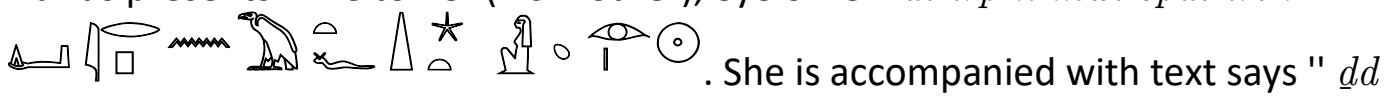
$m \underline{d w}$ in spdt nbt pt hr ib ntr nb hry ib hbit "words spoken by Sothis, the lady of sky, who is over all gods, who is worshipped at Hibis. ${ }^{76}$ Fig. 14

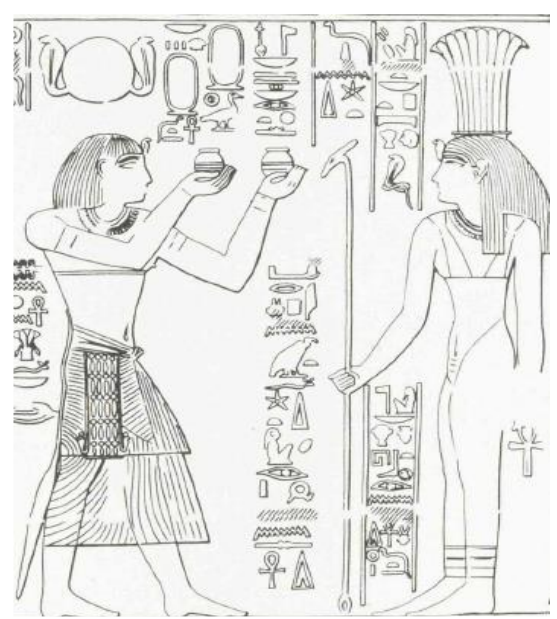

Fig. 14. A scene representing goddess Sopdet in a human form with a headdress like that of Anukis, temple of Hibis iii, south wall of room L,

After N. de G.Davies, The Temple of Hibis in El Khargeh oasis iii, New York, 1953, pl. 27

4-as a woman wears a disk upon her head containing a star

Goddess Sothis was represented, in a scene decorated the ceiling of temple of Deir El Haggar, in a boat together with the falcon who stands on a standard. She appears as a woman wearing a disk upon her head containing a star Fig. 15. 


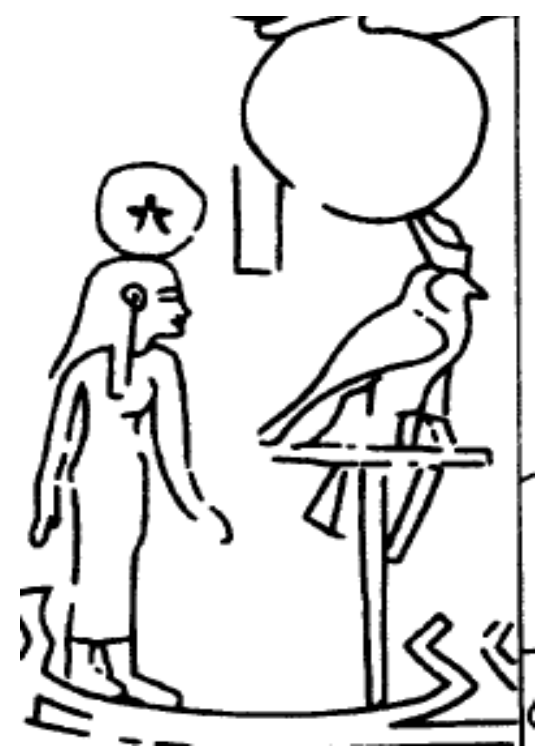

Fig. 15. A scene representing goddess Sopdet in a human form wearing a disk upon her head containing a star, temple of Deir El Haggar

After O.L. Kaper," the Astronomical Ceiling of Deir el Haggar in the Dakhleh Oasis", JEA 81, 1995, Fig. 1, p. 189

5-as a woman wears Hathoric crown

Goddess Sopdet appeared in A scene at the $1^{\text {st }}$ hypostyle hall of Edfu temple in the form of sitting goddess with hathoric crown and she is accompanied with her name

$h t$ hr iwnt spdt $\mid$

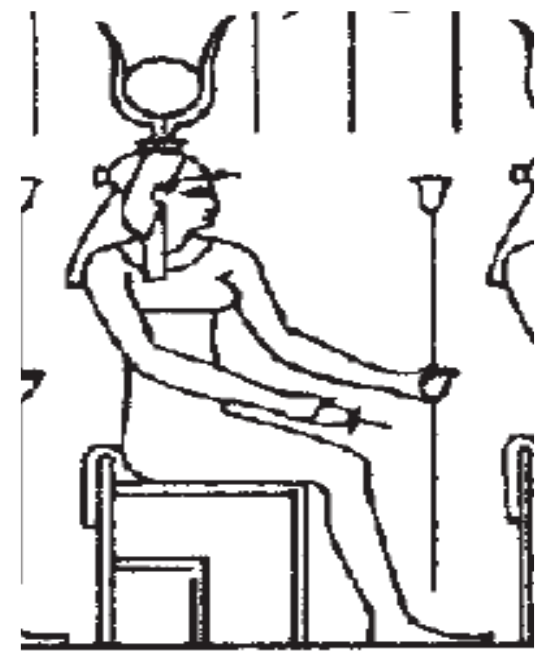

Fig. 16. A scene representing goddess Sopdet in a human form wearing hathoric headdress, temple of Deir El Haggar

After É. Chassinat , Le Temple d’Edfou III, Le Caire, 1928, pl. LXXIX 
6-goddess with white crown and two gazelle horns, surmounted with five pointed stars

Statue of goddess Sopdet preserved in British Museum, she appears in a human form in a standing attitude. She is shown wearing a crown like the white crown flanked from sides with two horns like that of goddess Satet and it is surmounted with five pointed stars. She is represented with one arm foded under her breast and the other one by her side. Fig. 17

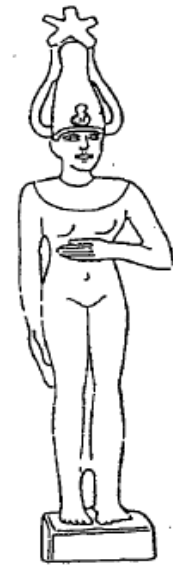

Fig.17. A Bronze statuette representing goddess Sopdet wearing tall crown surounded with two curved horns like Satet, and it is surmounted with five pointed star, British museum (BM 56-110).

After G. A. Hart, A Dictionary of Egyptian Gods and Godesses, London, 1987, p. 144

\section{B-Cow shapped goddess}

\section{1- as a recumbent cow}

Sopdet is represented here on an ivory tablet dating to reign of king $d r$ from $1^{\text {st }}$ dynasty, she is represented here as a lying cow with a plant between her horns ,symbolizing the year ${ }^{78}$. Under the shape of the cow appears sign resembles the $3 h t$ sign referring to her relation to the New year and the Nile innundiation. ${ }^{79}$ fig. 18

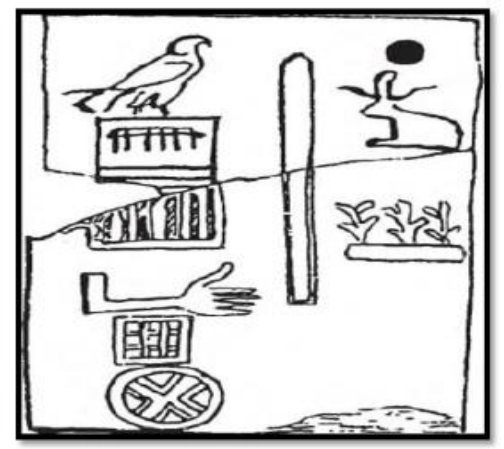

Fig.18. A scene representing goddess Sopdet as a recumbent cow, an ivory tablet, reign of king $\underline{d} r$ from $1^{\text {st }}$ dynasty

After M. Clagett, Ancient Egyptian Science, Volume II: Calendars, Clocks, and Astronomy, Philadelphia, 1995, fig. iii, 3b 
2-as a recumbent cow on her a celestial bark

Sopdet appears in the Zodiac of Dendera behind her consort sah (standing man, holding $w 3 s$ scepter), she is represented in the form of a recumbent cow on a celestial boat with five pointed stars between her horns. She is represented here in the same form of Hathor, referring to her assimilation to Hathor, and she is accompanied with her title $\llbracket \Delta_{\circ}^{\star} \circlearrowright \bigcup s p d t$ nbt wp rnpt " Sothis, lady of the beginning of the year.$^{80}$ She is followed by two figures of Satet and Anuket who signify the coming of the annual Nile flood, and it refers to the close relation between the heliacal rising of Sothis with the inundation ${ }^{81}$. Fig. 19 The simillar representation for goddess Sopdet as a recumbent cow decorted the Ceiling of hypostyle hall of Dendera temple Fig. 20.

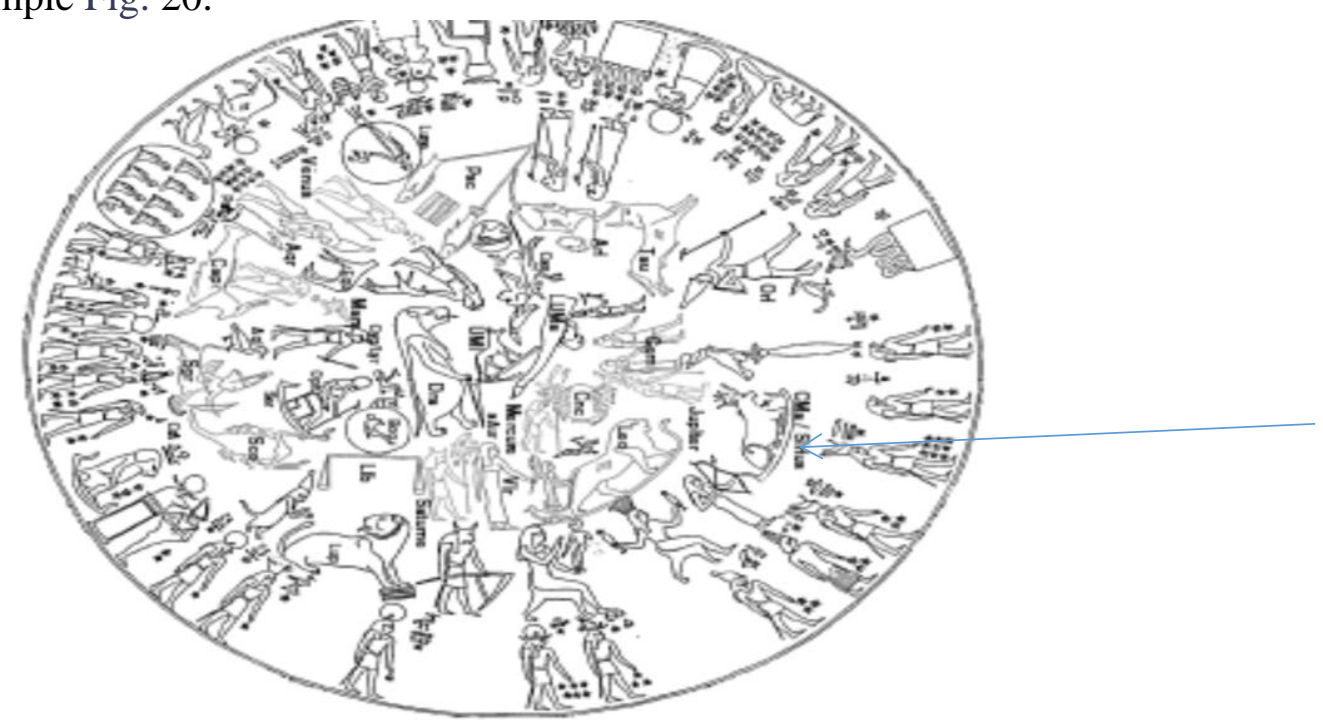

Fig.19. A scene representing goddess Sopdet as a recumbent cow on her celestial bark, the Zodiac of Dendera

After É. Aubourg, " la date de conception du zodiaque du temple d' Hathor à Dendera", BIFAO 95, 1995, fig. 2

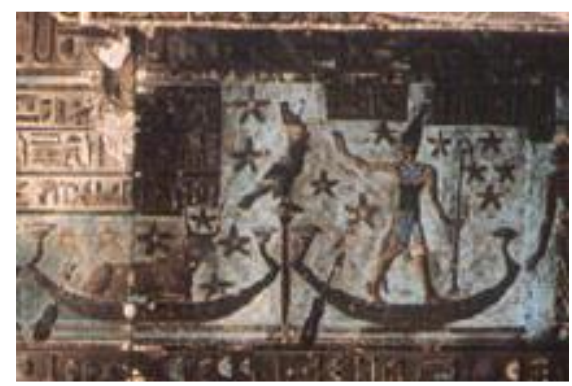

Fig. 20 A scene representing goddess Sopdet as a recumbent cow on her celestial bark, Ceiling of the hypostyle hall of Dendera temple

After M. Shaltout, The Ancient Egyptian monuments and their relation to the position of the sun, stars and planets. Epilogue to Serabit El-Khadem and overview, le Caire, 2008, fig 6. 22 
C-Sopdet is represented during the roman era in her form as Isis Sothis while riding on a dog

Statue of goddess Sopdet in her form Isis Sothis in Berlin Museum. She appears in a human form riding side - saddle on a dog (her symbolic animal) fig. 21

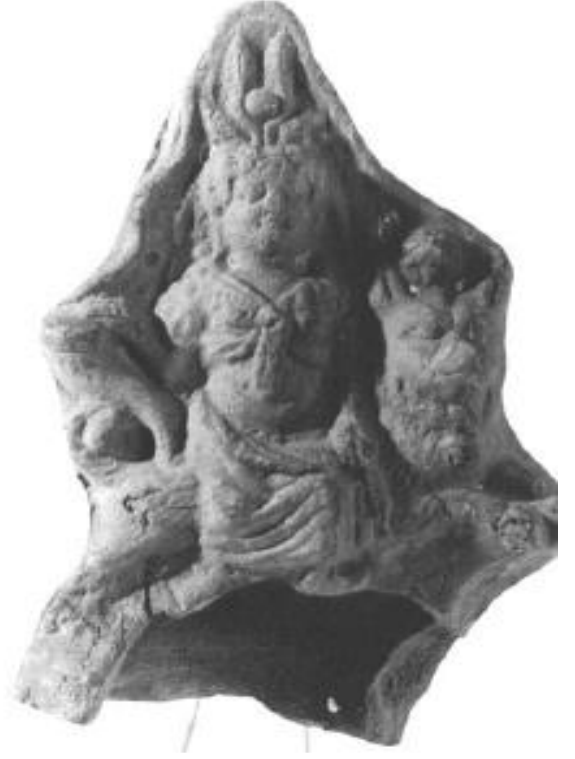

Fig.21. A statue representing goddess Isis Sothis on a dog, Berlin Museum, 9956, Roman era

After R.S. Bianchi, " Pharaonic Egyptian Elements in the Decorative Arts of Alexandria during the Hellenistic and Roman Periods",in J.P. Getty, Alexandria and alexandrianism , California, 1993, fig. 2

\section{$D$ as a dog headed snake}

Sothis appeared as a dog headed snake on amagical gems made out of Cornelian, exposed at Berlin museum ${ }^{82}$ Fig. 22

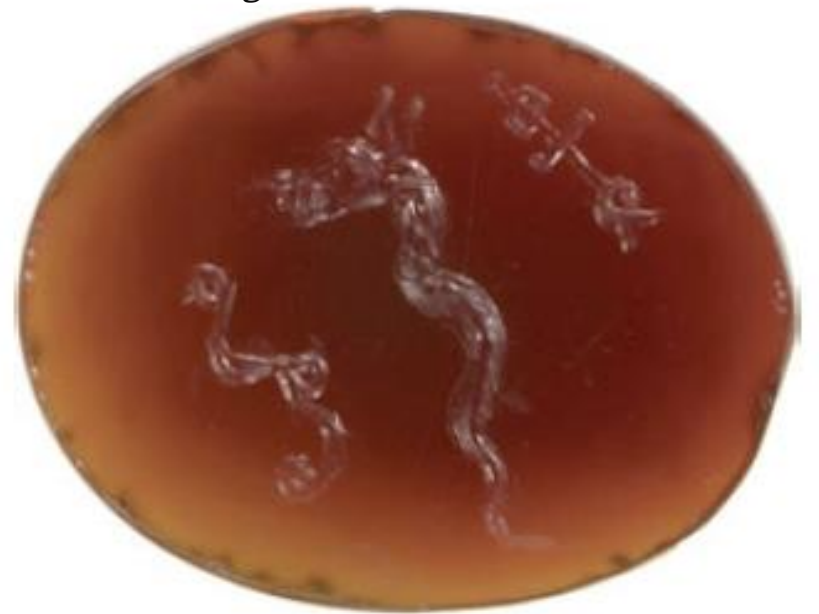

Fig. 22. Sothis as a dog headed snake, Cornelian magical gems, Berlin Museum, Roman era

After D. Gruyter, Bild und Schrift auf 'magischen' Artefakten, Heidelberg, 2018, fig. 31 


\section{E-Lion shapped goddess}

1 sitting lion-headed goddess

Goddess Sopdet is represented as a sitting lioness headed goddess with uraeus upon her head in Hibis temple. The king is represented while presenting sistrum to goddess Sopdet who sits on a throne inside a shrine Fig. 22.

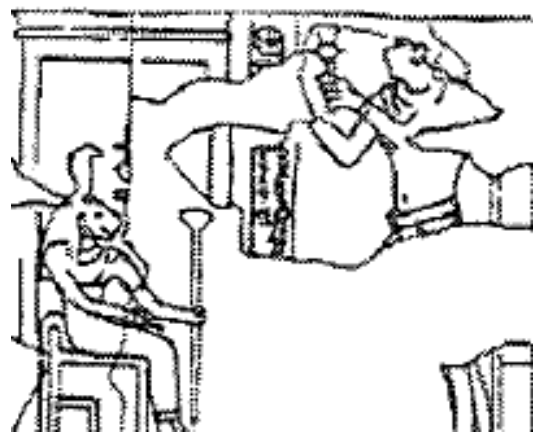

Fig.23. Ascene representing Sopdet as a sitting lioness headed goddess, Hibis temple

After F.T. Ismail, cult and ritual in Persian period Egypt, Baltimore, 2009, fig. 41

2- lion-headed snake

goddess Sopdet was represented as a lioness headed snake encircled the cartouch of the king at the lintel of the Western wall of offering hall $T$ at Dendera temple, she is accompanied with her name spt Fig. 24

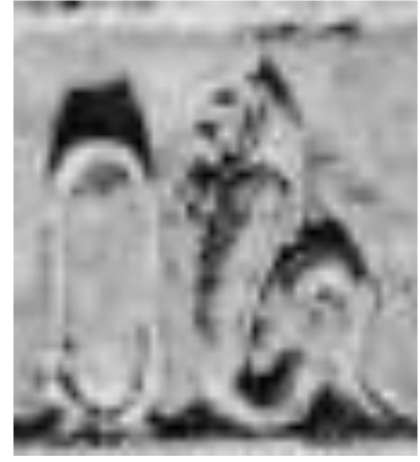

Fig. 24. Ascene representing Sopdet as lion-headed snake, Dendera temple

After É. Chassinat, Le Temple de Dendara vii, le Caire, 1972, pl. DCXXXV

She is associated with Nephtys, she is called nebet Het the great, the mistress, lady of life of the two lands

\section{Assimilation and relation with other deities}

\section{$1-s 3 h$ (Orion)}

She associated to Osiris as in the pyramid texts it is mentioned that they united together to give birth to the morning star (Venus) ${ }^{83}$. She always appeared while following $s 3 h$ (Orion) in the southern sky, as if protecting him from his enemy mshtyw (the northern sky) which related to god $\operatorname{Seth}^{84}$

2-She is associated to Isis 85 
* From text inscribed at obelisk honouring emperor Domitian and Isis at museum of Sannio in Benevento, Italy

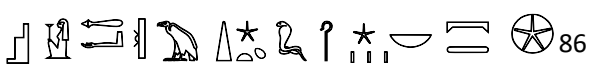

ist c3t mwt spdt h.k 3 dw3w nb(t) pt t3 dwst

Isis, the great, the God's Mother, Sothis, Queen of the Gods, Lady of the Sky, the Earth, and the Netherworld.

*From text inscribed at pillar JE 65061

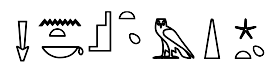

snt.k ist $\mathrm{m}$ spdt

your sister is Isis Sothis ${ }^{87}$

*From text inscribed at pronaos of dendera ${ }^{88}$

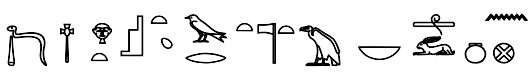

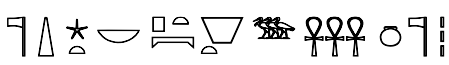

$\underline{d d} m \underline{d}$ w ind $\underline{d}$ hrt ist wrt mwt ntrt nbt swnt spdt nbt pt hnnwt b3w enhww nw ntrw

Words spoken, praises to goddess Isis, the divine mother, lady of Aswan, Sothis , the lady of sky, mistress of living souls of the gods

3-She is associated to Nephtys

*from text inscribed at the Canopic Box of ns c $r w d "$ (BM EA 8539)

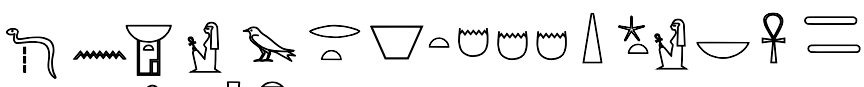

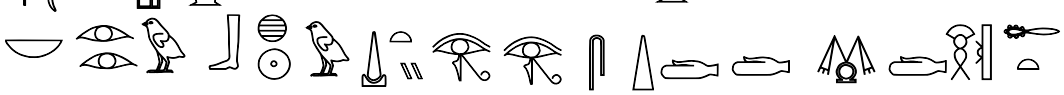

dd mdw in nbt-ht wr(t) hnwwt hmwt spdt nb(t) enh t3wy nbt irty wbh (t) wdisty $\operatorname{spd}(t) d m d w 3 h\{t) \underline{h} t$

Words spoken by Nephthys, the great one, the mistress of women, Sothis, lady of Ankhtawy (Memphis), lady of the two eyes, shining of eyes, sharp of knife, enduring of body. ${ }^{89}$ Fig. 25 


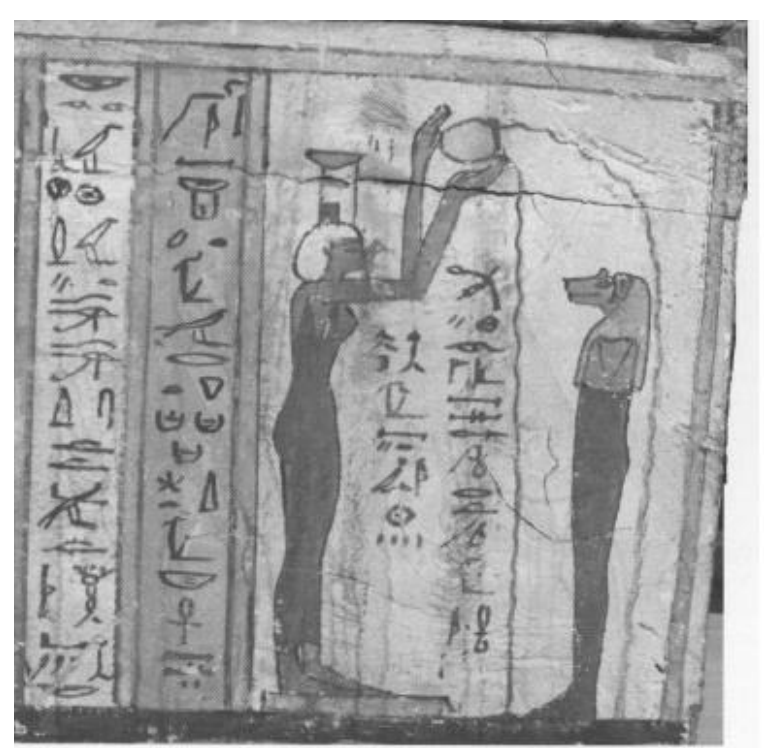

Fig. 25. A text inscribed at the Canopic Box of $n s$ c $3 r w d^{\prime \prime}$ (BM EA 8539), 26 ${ }^{\text {th }}$ dynasty After A.M. Mekawy, " the Canopic Box of $n s$ (3 rwd" (BM EA 8539), JEA 98, 2012, fig. 1 4-She is associated to

*from hymens of goddess Anukis in her temple at Komir 90

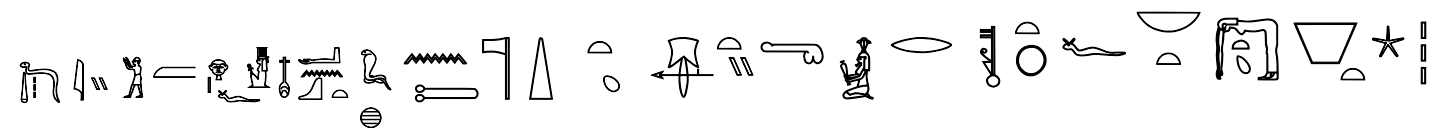
$\underline{d} d m \underline{d} w i 3 w m$ hr. f nfr enkt $n \underline{t}$ spdt sti ḩpy $r$ gnwt.f nb hryt ḥnwt sb3w Words spoken, adoration to your beautiful face Anukis, To you Sothis, who throws the flood in its time, mistress of the heaven, lady of all stars

5 -She is associated to wrt hekaw

*from hymens of goddess wrt hekaw

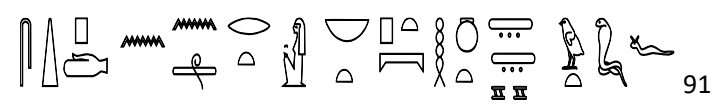

spdt n nsrt nbt pt hnwwt t3wy wrt hkß3w

Sothis of the flame, the lady of the sky, mistress of two lands weret Hekaw

6-She is associated to Bastet

*from text inscribed at Edfu temple

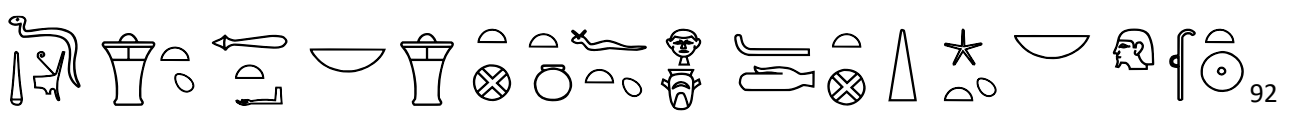

$\underline{d} d$ mdw in b3stt c $3 t$ nbt b3st tfnt hry ib bhdt spdt nbt tp rnpt

Words spoken by goddess Bastet, the great one, the lady of bubastis, Tefnt, who is worshipped at Edfu, Sothis, lady of the first year 
7-She is associated to Hathor

*Hathor is addressed as Sothis at Dendera temple

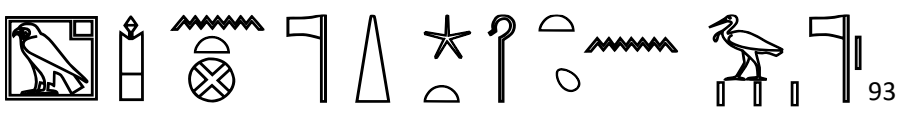

ht hr iwnt ntr spdt ḩk3t $n$ b3w ntr

Hathor goddess of Dendera, Sothis, queen of divine spirits

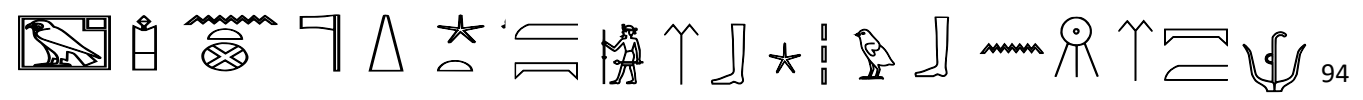

ht hr iwnt ntr spdt $m$ pt ity sb3w wbn m pt wp rnpt

Hathor, goddess of Dendera, Sothis in the sky, sovereign of stars, rising in the sky in the beginning of the year

8--She is associated to Satet

Sopdet appeared in the same form of Satet in her bronze statuette at British museum ( BM 56-110), where she wears a crown surounded with two curved horns like Satet, and it is surmounted with five . pointed star. goddess Satet from the potolomic period carried mant epithets like that of Sopdet like, mistress of the beginning of the year,goddess of the eastern horizon of the sky, the great one in the sky, Lady of stars, ruler of stars, and eye of Re. ${ }^{95}$

\section{her functions and roles}

- Bringer for the innundation

At temple of Dendera, southwest corner of the enclosure wall

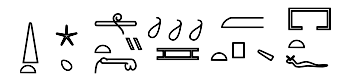

spd.t sty hepy $m$ tph.t.f

"Sothis, who pours out Hapy from his cavern"96

This text assures her responsbility for the inundation as she poursout Hapy in his cavern to flood the Two Lands, which will lead to the earth's fertility97

- During Old Kingdom she guided the deceased king in the herafter

- During Middle Kingdom and New Kingdom, she became as a mother or a nurse

\section{Titles}

From the previous studied texts, it is concluded that goddess Sopdet carried many titles like:

spdt sti hepy r gnwt.f nb hryt hnwt sb3w (Sothis, who throws the flood in its time, mistress of the heaven, lady of all stars ) ${ }^{98}$, spdt $n$ nsrt nbt pt hnwt $t 3 w y$ (Sothis of the flame, the lady of the sky, mistress of two lands ${ }^{99}$, is imyt $3 h t$ (who is in the horizon ) ${ }^{100}$, spdt nbt pt hr ib ntr nb hry ib hbit (Sothis, the lady of sky, who is 
over all gods, who is worshipped at Hibis ${ }^{101}$, spdt nbt wp rnpt ( Sothis, lady of the beginning of the year) ${ }^{102} s p d t h k 3 \quad d w 3 w n b(t) p t t 3 d w 3 t$ (Sothis, Queen of the Gods, Lady of the Sky, the Earth, and the Netherworld ${ }^{103}$, nbt swnt spdt nbt pt hnwt $b 3 w$ enhw nw ntrw (lady of Aswan, Sothis , the lady of sky, mistress of living souls of the gods $)^{104}$, spdt $n b(t)$ cnh t3wy nbt irty wbh (t) wd $3 t y$ spd(t) dmd w3h $\{t$ t) $\underline{h} t($ Sothis, lady of Ankhtawy (Memphis), lady of the two eyes, shining of eyes, sharp of knife, enduring of body ) ${ }^{105}$, spdt rnpyt rnpt ntrt $m$ mswt.s tpy rnpt (Sopdet is the young, she is of the year, a goddess from her birth is the start of the year), spdt nbt tp rnpt ( Sothis, lady of the first year) ${ }^{106}$, spdt hkst $n$ b3w ntr (Sothis, queen of divine spirits ) ${ }^{107}$, spdt $m$ pt ity sb3w wbn $m$ pt wp rnpt (Sothis in the sky, sovereign of stars, rising in the sky in the beginning of the year) ${ }^{108}$

\section{From the previous titles it is concluded that she was worshipped at the following centers:}

Hibis: spdt nbt pt hrr ib ntr nb hry ib hbit (Sothis, the lady of sky, who is over all gods, who is worshipped at Hibis

Aswan: nbt swnt spdt nbt pt (lady of Aswan, Sothis, the lady of sky

Memphis: spdt $n b(t)$ enh t3wy (Sothis, lady of Ankhtawy (Memphis)

She was associated also with Hathor and she was worshipped at her cult center (Dendera) ht hr iwnt ntr spdt (Hathor goddess of Dendera, Sothis)

\section{her Qualitity}

It is concluded from the titles and the studied texts that this goddess is characterized with the following qualities:

stellar goddess: Most of her titles indicate that she is astral goddess like spdt nb hryt hnwt $s b 3 w$ (Sothis, mistress of the heaven, lady of all stars ), spdt nbt pt (Sothis , the lady of the sky), is imyt 3ht (who is in the horizon ), spdt nbt wp rnpt (Sothis, lady of the beginning of the year), spdt nbt tp rnpt ( Sothis, lady of the first year), spdt $m$ pt ity sb3w wbn $m$ pt wp rnpt (Sothis in the sky, sovereign of stars, rising in the sky in the beginning of the year)

Goddess of fertility: she was known as a harbinger of the innundation, so she was considered as a fertility goddess because of the soil braught by the flood spdt sti hepy $r$ gnwt.f (Sothis, who throws the flood in its time)

Strong godddess : she was known as the sharp goddess, besides she was associated with wrt hekaw who was known with her strength spdt $n$ nsrt (Sothis of the flame), $s p d t \operatorname{spd}(t) d m d$ ( Sothis, sharp of knife) 


\section{Conclusion and results}

\section{From this study it is concluded that:}

- The name of Sopdet appeared in many forms through the different periods, and in several forms it ended with one of the following determinatives $*$, กी 0 referring that she is a female one and also she is one of the astral deities.

- Sopdet carried many titles like Sothis, who throws the flood in its time, mistress of the heaven, lady of all stars, Sothis of the flame, the lady of the sky, mistress of two lands, who is in the horizon, Sothis, the lady of sky, who is over all gods, who is worshipped at Hibis, Sothis, lady of the beginning of the year, Sothis, Queen of the Gods, Lady of the Sky, the Earth, and the Netherworld, lady of Aswan, Sothis, the lady of sky, mistress of living souls of the gods, Sothis, lady of Ankhtawy (Memphis), lady of the two eyes, shining of eyes, sharp of knife, enduring of body, Sopdet is the young, she is of the year, a goddess from her birth is the start of the year, Sothis, lady of the first year,Sothis, queen of divine spirits ,Sothis in the sky, sovereign of stars, rising in the sky in the beginning of the year.

- Sopdet was worshipped at many cult centres like Hibis, Aswan, Memphis, and Dendera

- She appeared in different forms as she appeared as a human, a cow, a dog headed serpent, a lion headed sepent, a lion headed goddess, and a human form riding side - saddle on a dog 109

- She was distinguished as a stellar goddess, she was known with her strength, and her fertility .

- She was associated and identified with many deities like Isis, Hathor, Weret Hekaw, Anokis, and Bastet.

- During old kingdom she was considered as goddess of innundation, and also, she guided the deceased king in the herafter, while during Middle kingdom she became as a mother or a nurse

- The dead king in the sacred spells compared himself with various a stral gods, like Orion, and Sothis to get back life and strength to be able to walk in the sky ${ }^{110}$

\section{Bibliography}

${ }^{1}$ Sah was the personified god for the southern constellation known as Orion, and he was the father in the triad consisted of sah, Sopdet as the mother and their son was sopdu, he is manifestated to Osiris in the pyramid texts as he was mentioned as the father of gods; R. H. WILKINSON, The complete gods and goddesses of Ancient Egypt ,Cairo, 2003, p. 127

${ }^{2}$ Sopdu was the god of the eastern borders. He is represented as a crouching falcon or Bedouin warrier wearing a crown of tall feathers with long hair and pointed beard. His main cult center was at saft el henna ( per sopdu) and he was worshipped together with Hathor at Serabbit el khadem ; G. Hart, The Routledge Dictionary of Egyptian Gods and Goddesses, London, 2005,p.151.

3 L. Depuydt, "Sothic Chronology and the Old Kingdom", JARCE 37, 2000, p. 168

${ }^{4}$ Joachim Friedrich Quack, Astronomy in Ancient Egypt, Oxford, 2018, p.3

${ }_{5}^{5}$ L.S. Bull, " An Ancient Egyptian Astronomical Ceiling-Decoration", The Metropolitan Museum of Art Bulletin, Vol. 18, No. 12, Nov., 1923, p. 286 
${ }^{6}$ M. Hammam, " The Astral and Solar Destinies of the Deceased in the Ancient Egyptian Texts", Journal of the Faculty of Tourism and Hotels-University of Sadat City, Vol. 4, Issue (2/1), December, 2020, p.24

${ }^{7}$ P. McKechnie, J. A. Cromwell, Ptolemy I and the Transformation of Egypt, 404-282 BCE , Brill, 2018, p. 130

${ }^{8}$ D. Martin, Nature, Maat and Myth in Ancient Egyptian and Dogon Cosmology, Philadelphia, 2001, p. 149

${ }^{9}$ R. A. Wells, " Origin of the Hour and the Gates of the Duat", SAK 20, 1993, p. 309

${ }^{10}$ E. Theodossiou, V. Manimanis, M. Dimitrijevic, \& P. Mantarakis, " Sirius in Ancient Greek and

Roman Literature", Journal of Astronomical History and Heritage 14(3), 180-189 (2011), p.180

${ }^{11} \mathrm{~Wb}$ IV, P. 111-112

${ }^{12}$ Pyr. 341c, PT 263; Pyr. 151b, PT 609

${ }^{13}$ Pyr. 363a, PT 266

${ }^{14}$ Pyr.458a, PT 302 ; Pyr.1482, PT 573

${ }^{15}$ Pyr.632c, PT 366

${ }^{16}$ Pyr.632d, PT 366

${ }^{17}$ Pyr.689, PT 393

${ }^{18}$ R. O.FAULKNER, The Ancient Egyptian Coffin Texts I, (Warminstar, 1973), p. 3

${ }^{19}$ Ibid., p. 26

${ }^{20}$ Ibid., p. 36

${ }^{21}$ R. O.FAULKNER, The Ancient Egyptian Coffin Texts II, (Warminstar, 1975), p.95

${ }^{22}$ Ibid., p. 99

${ }^{23}$ Ibid., p. 101

${ }^{24}$ Loc. Cit.

${ }^{25}$ Ibid., p. 207

26 L. Günther, The Papyrus of Nebseni (BM EA 9900), london, 2004, sheet 17, p. 33-34

27 R.A. Parker, The Calendars of Ancient Egypt, Chicago, 1950, p. 33

28 M. Shaltout, The Ancient Egyptian monuments and their relation to the position of the sun, stars and planets. Epilogue to Serabit El-Khadem and overview, le Caire, 2008, p 181

29 A.M. Mekawy, " the Canopic Box of Ns 3 rwd"'(BM EA 8539), JEA 98, 2012, P. 137

30 N. de G. Davies, The temple of Hibis in el Khargeh Oasis. The decoration, New York, 1953,p. 23

${ }^{31}$ E. Chassinat, Le Temple de Edfu III, le caire,1928, p. 302

${ }^{32}$ A. Erman, " Die Obelisken der Kaiserzeit", ZÄS 34, 1896, P. 153

${ }^{33}$ M. Es-Saghir, D. Valbelle, "Deux hymnes aux divinités de Komir : Anoukis et Nephthys", BIFAO 83, 1983,P. 161

${ }^{34}$ A. Erman, Hymnen an das Diadem der Pharaonen : aus einem Papyrus der Sammlung Golenischeff, Berlin, 1911, p. 25

${ }^{35}$ E. Chassinat, Le Temple de Edfu I, le caire,1892, p. 496

36 E. Chassinat, Le Temple de Dendara I, le caire, 1934, p. 98

${ }^{37}$ Pyr. 151b, pt 216

${ }^{38}$ Pyr. 341c, PT 263; Pyr. 151b, PT 609

${ }^{39}$ Pyr. 357 a, PT 265

${ }^{40}$ Pyr. 363a, PT 266

${ }^{41}$ Pyr.458a, PT 302 ; Pyr.1482, PT 573 
${ }^{42}$ Pyr.459a, PT 302

${ }^{43}$ Pyr.632c, PT 366

${ }^{44}$ Pyr.689, PT 393

${ }^{45}$ Pyr. 723a ,PT 412.

${ }^{46}$ Bianca van Sittert, "Maintaining Order over Chaos": A study of the ba and baw concepts in the

Predynastic Period, Early Dynastic Period, and Old Kingdom", Master's thesis, the American

University in Cairo, 2020, p. 84

${ }^{47}$ Sothis makes a third with King and Orion .

${ }^{48}$ Pyr. 929b ,PT 473 .

${ }^{49}$ Pyr. 935c ,PT 473 .

${ }^{50}$ pyr965a-b, PT 477

${ }^{51}$ Pyr1082d-b, PT 504

${ }^{52}$ Pyr1152b-b, PT 511

${ }^{53}$ Pyr1123b-b, PT 509

${ }^{54}$ Pyr1437a-b, PT 569

${ }^{55}$ Pyr 1561 b, PT 582

${ }^{56}$ R. O.FAULKNER, The Ancient Egyptian Coffin Texts I, (Warminstar, 1973), p. 3

${ }^{57}$ Ibid., p. 26

${ }^{58}$ Ibid., p. 36

${ }^{59}$ K. Goebs, Crowns in Egyptian Funerary Literature Royalty, Rebirth, and Destruction,Oxford, 2008, p. 203

${ }^{60}$ R. O.FAULKNER, The Ancient Egyptian Coffin Texts II, (Warminstar, 1975), p.95

${ }^{61}$ Ibid., p. 99

${ }^{62}$ Ibid., p. 101

${ }^{63}$ Ibid., p. 101

${ }^{64} \mathrm{~K}$. Goebs, op. cit., p. 16

${ }^{65}$ Ibid., 272

${ }^{66}$ R. O.FAULKNER, The Ancient Egyptian Coffin Texts II, p. 101

${ }^{67}$ Ibid., p. 127

${ }^{68}$ Ibid., p. 207

${ }^{69}$ Ibid., p. 253

70 L. Günther, The Papyrus of Nebseni (BM EA 9900). , london, 2004, sheet 17, p. 33-34

71, E.A.W. Budge, The Book of the Dead: The Chapters of Coming Forth by the Day, London, 1898, p. 7

${ }^{72}$ R. O.FAULKNER, The Ancient Egyptian Coffin Texts I, p. 3

${ }^{73}$ M.H. Beatty, " the image of Celestial Phenomena in the Book of coming Forth by Day. An astronomical and Philological Analysis",Doctor of Philosophy, Temple University , 1998, p. 169

${ }^{74}$ M. Jordan, Dictionary of Gods and Goddesses, New York, 2004, 206

${ }^{75}$ R.A. Parker, the Calendars of Ancient Egypt, Chicago, 1950, p. 33

${ }^{76}$ N. de G. Davies, The temple of Hibis in el Khargeh Oasis. The decoration, New York, 1953,p. 23

${ }^{77}$ Edfu III, p. 302

${ }^{78}$ I. Shaw, Ancient Egyptian Technology and Innovation, London, 2012, p. 160

${ }^{79}$ R.A. Parker, the Calendars of Ancient Egypt, p. 32

${ }^{80}$ M. Shaltout, stars and planet, $\mathrm{p} 181$

${ }^{81}$ G. Priskin," the Dendera Zodiacs as narratives of the Myth of Osiris, Isis, and the Child Horus", ENIM 8, 2015, p. 136 
${ }^{82}$ P. Vitellozzi, Relations between Magical Texts and Magical Gems recent perspectives, Heidelberg, 1979, p. 220, fig. 31

${ }^{83}$ F. Fleming, The Way to Eternity: Egyptian Myth, London, 2003, p. 56

${ }^{84}$ L. Kákosy, " Sothis " in E. Otto ed., LÄ V, Wiesbaden, 1984, col 1111.

${ }^{85}$ M. Jordan, Dictionary of Gods and Goddesses, New York, 2004, p. 206

${ }^{86}$ A. Erman, " Die Obelisken der Kaiserzeit", Z̈̈S 34, 1896, P. 153

87 KRI III, 192

${ }^{88}$ M. A. Stadler, " Der Isishymnus E.14 aus dem Isistempel von Assuan", JEA 98, 2012, p 296

${ }^{89}$ A.M. Mekawy, " the Canopic Box of $\mathrm{N} s$ (3,p. 137

${ }^{90}$ M.-Saghir, D. Valbelle, "Deux hymnes aux divinités de Komir : Anoukis et Nephthys", BIFAO 83, 1983,161

${ }^{91}$ A. Erman, Hymnen an das Diadem der Pharaonen, p. 25

${ }^{92}$ E. Chassinat, Le Temple de Edfu I, le caire,1892, p. 496

93 D I, p. 98

${ }^{94}$ D III, p. 35

95 R.A. Wells, "Sothis and the Satet Temple on Ele phantine", SAK 12, 1985, P. 259

${ }^{96}$ D III, 74,12-13.

${ }^{97}$ R. Barbara, The Theology of Hathor of Dendera: Aural and Visual Scribal Techniques in the Perwer Sanctuary, California, 2012, p. 196

98 M.El Saghir, D. Valbelle, "Anoukis et Nephthys",161

${ }^{99}$ A. Erman, Hymnen, p. 25

${ }^{100}$ R. O.FAULKNER, The Ancient Egyptian Coffin Texts I, p. 3

${ }^{101}$ N. de G. Davies, The temple of Hibis in el Khargeh Oasis,p. 23

102 M. Shaltout, The Ancient Egyptian monuments and their relation to the position of the sun, $\mathrm{p} 181$

103 A. Erman, " Die Obelisken der Kaiserzeit", ZÄS 34, 1896, P. 153

${ }^{104}$ M. A. Stadler, " Der Isishymnus E.14 aus dem Isistempel von Assuan", JEA 98, 2012, p 296

105 A.M. Mekawy, " the Canopic Box of Ns Aa rwd" (BM EA 8539), JEA 98, 2012, P. 137

${ }^{106}$ E I, p. 496

107 D I, p. 98

${ }^{108}$ D III, p. 35

${ }^{109}$ CHR.LEITZ, Lexicon der Ägyptischen Götter und Götterbezeichnung VI, OLA112, ( Leuven- Paris, 2002),P. 292.

110 K. Goebs, Crowns in Egyptian Funerary Literature Royalty, p. 167 


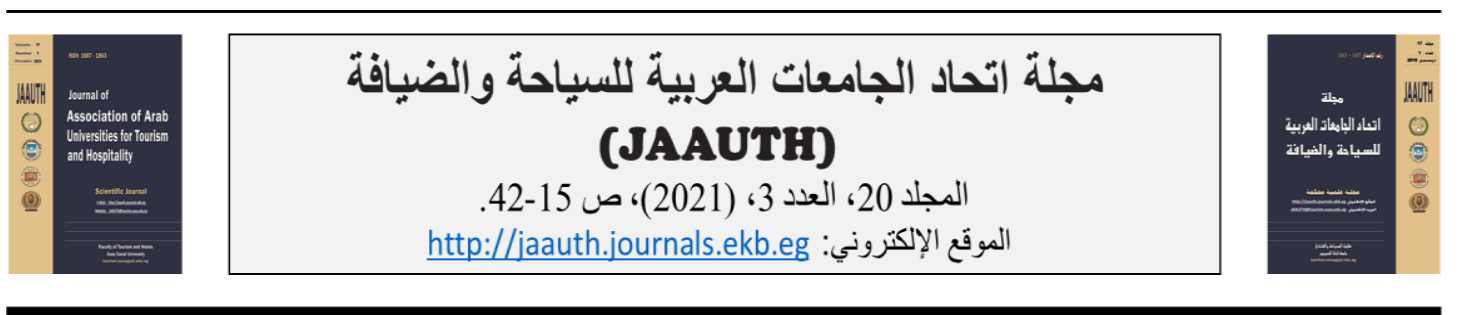

\section{المعبودة سوبدت فى مصر القديمة \\ مني عز علي \\ كلية السياحة والفنادق، جامعة المنصور}

\begin{tabular}{|c|c|}
\hline الملخص & معلومات المقالة \\
\hline 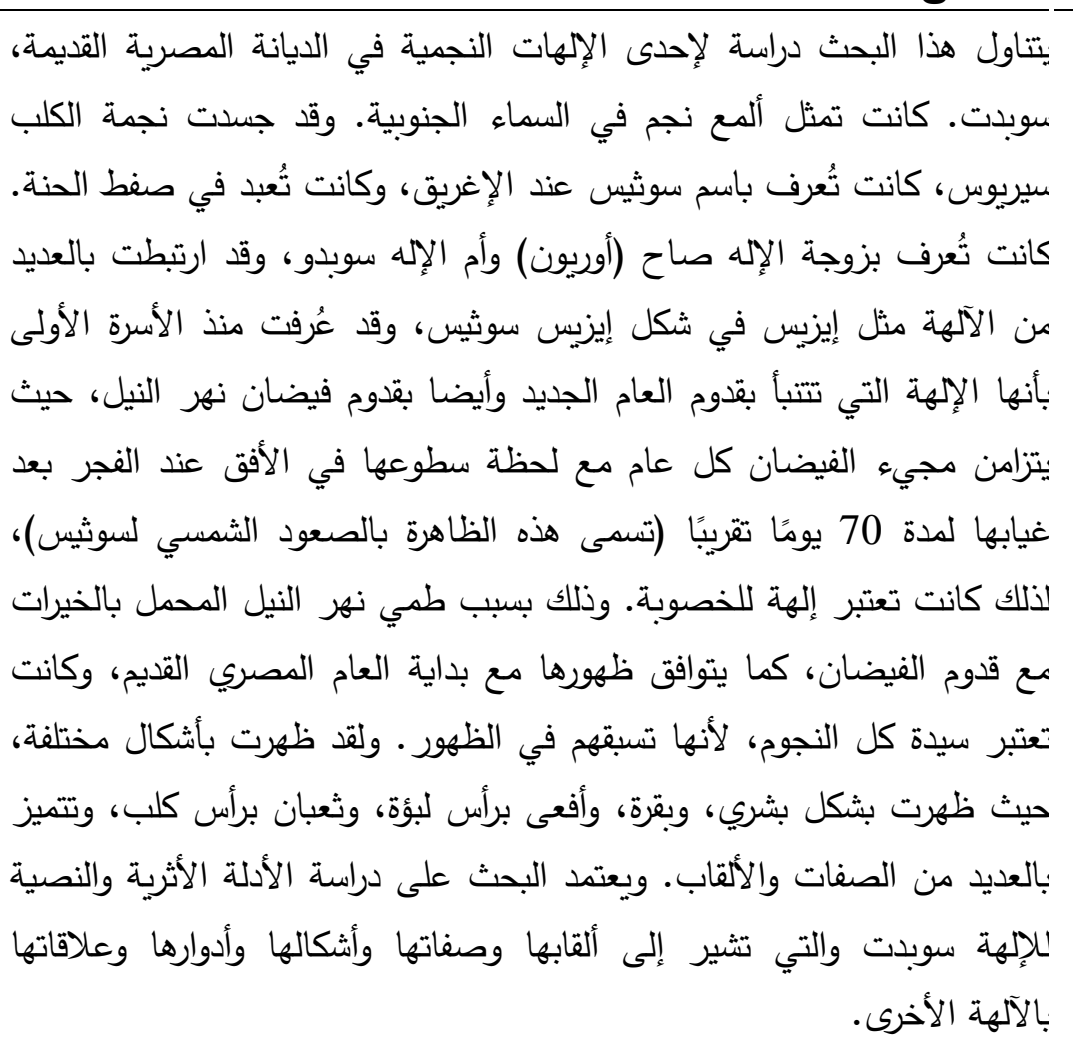 & 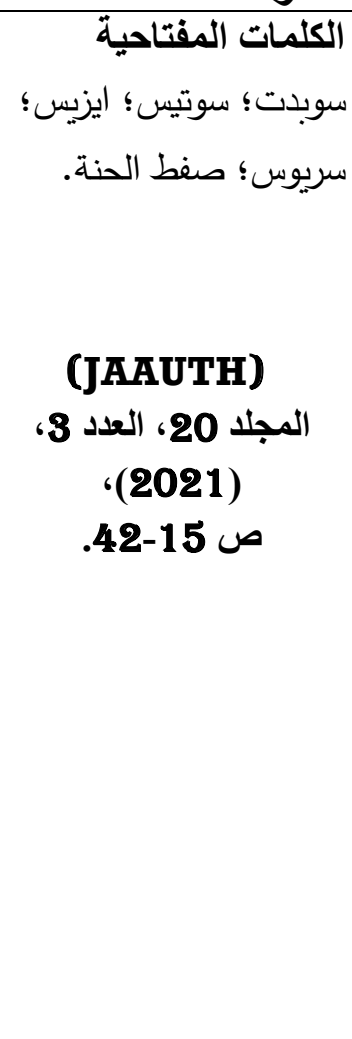 \\
\hline
\end{tabular}

